\title{
MOTIVASI ANAK BELAJAR DARI RUMAH MELALUI KEGIATAN PUNCAK TEMA
}

\author{
Nursamsi $^{1}$, Ine Nirmala ${ }^{2}$, Feronica Eka Putri ${ }^{3}$ \\ Pendidikan Islam Anak Usia Dini, Fakultas Agama Islam, Universitas Singaperbangsa \\ nur0305nursamsi@gmail.com, ine.nirmala@staff.unsika.ac.id, feronica.ekaputri@fai.unsika.ac.id. \\ Nursamsi. Ine Nirmala. Feronica Eka Putri. (2021). Motivasi Anak Belajar dari Rumah Melalui Kegiatan \\ Puncak Tema. Jurnal Pelita PAUD, 6(1), 127-134. \\ doi: https://doi.org/10.33222/pelitapaud.v6i1.1415
}

Abstrak:. Penelitian ini bertujuan untuk mengamati motivasi belajar anak pada saat BDR melalui kegiatan puncak tema "tanaman". Kegiatan ini dirancang untuk menambah pengalaman yang beragam serta mengurangi pembelajaran dengan menggunakan lembar kerja siswa pada saat kegiatan belajar dari rumah. Salah satu tantangan yang dihadari pada saat belajar dari rumah yaitu tidak adanya interaksi secara langsung antara guru dan anak sehingga motivasi anak menjadi rendah dan kurang maksimal Metode dalam penelitian ini yaitu metode kualitatif deskriptif, data yang diperoleh melalui dokumentasi dilakukan selama kegiatan BDR yang dikirim oleh orangtua kepada guru melalui aplikasi whattsap, wawancara dilakukan kepada orangtua dan guru kelas B TKQ An Namlu dan observasi kepada a anak. Hasil penelitian menunjukkan bahwa kegiatan puncak tema "tanaman" dapat menambah motivasi anak dalam pembelajaran sehingga hasil belajar anak mengalami perubahan yang maksimal.

Kata kunci: motivasi belajar anak, belajar dari rumah, puncak tema

Abstract: This study aims to observe children's learning motivation during BDR through the peak activity of the "plant" theme. This activity is designed to add a variety of experiences and reduce learning by using student worksheets during learning activities from home. One of the challenges faced when learning from home is that there is no direct interaction between teachers and children so that children's motivation is low and less than optimal. The method in this study is descriptive qualitative method, the data obtained through documentation was carried out during BDR activities sent by parents to teachers through the WhatsApp application, interviews were conducted with parents and teachers of class B TKQ An Namlu and observations to 20 children. The results showed that the peak activity of the "plants" theme can increase children's motivation in learning so that children's learning outcomes experience maximum changes

Kevwords: children's learning motivation. learning from home. the highlight of the theme

http://jurnal.upmk.ac.id/index.php/pelitapaud 


\section{PENDAHULUAN}

Pendidikan Anak Usia Dini (PAUD) merupakan pendidikan pra sekolah atau jenjang pendidikan sebelum pendidikan dasar. Usia pra sekolah ini berada pada rentang usia 0-6 tahun, dimana pembelajarannya bertujuan untuk merangsang atau menstimulus perkembangan anak usia dini secara menyeluruh. Anak usia dini merupakan masa "golden age" dimana pada masa ini pertumbuhan dan perkembangan merupakan proses yang paling penting karena sekitar $80 \%$ otak anak berkembang sehingga pada masa ini merupakan masa emas bagi kehidupan seorang anak (Sugiyono, 2015). Anak dapat menyerap berbagai informasi dengan cepat tanpa (Sugiyono, 2015) melihat baik dan buruknya. Tugas dari orangtua dan gurulah dalam menambah pengetahuan anak serta mengajarkan perilaku yang baik, selain itu juga sebagai panutan bagi anak orangtua dan guru tidak hanya mengajarkan dan mengarahkan akan tetapi selalu memberikan contoh yang baik dan benar.

Dalam QS. At-Tahrim (66) ayat 6. Allah swt berfirman, "Hai orang-orang yang beriman, peliharalah dirimu dan keluargamu dari api neraka". Ayat tersebut menjelaskan bahwa kewajiban orangtua dalam mendidik anak-anaknya agar terhindar dari siksaan api neraka. Anak yang merupakan amanah yang telah dititipkan Allah SWT kepada orangtua. Ketika kita telah diberikan amanah tugas kita adalah menjaga dengan baik, kita memperlakukan amanah ini sesuai dengan keinginan dari yang memberi amanah. Karena anak merupakan amanah, berarti orangtua harus menjaganya dengan sebaik-baiknya dengan cara merawat, menjaga dan mendidik sesuai perintah Allah SWT.

Pada akhir tahun 2019 penduduk dunia di kagetkan dengan penyakit baru yang berasal dari virus Corona SARS-Cov-2 atau COVID-19 termasuk negara Indonesia. Berbagai bidang kehidupan mengalami berbagai hambatan, tak terkecuali dengan bidang pendidikan. Pemerintah Menteri Pendidikan dan Kebudayaan (Mendikbud) Nadiem Anwar Makarim mengeluarkan mengeluarkan Surat Edaran Nomor 4 Tahun 2020 tentang pelaksanaan pendidikan dalam masa pandemic covid-19 salah satunya yaitu dengan sistem pembelajaran jarak jauh yang dilakukan dengan cara daring atau dalam istilah BDR (Belajar dari Rumah), Permasalahan pun mulai bermunculan dengan sistem pembelajaran ini, salah satunya yaitu hasil belajar yang anak kurang maksimal, hal ini dirasakan oleh guru kelas B di TKQ An Namlu Karawang yang dilihat dari rekapan hasil penilaian anak pada akhir pembelajaran semester ganjil dengan ditemukannya pada pra obsevasi terdapat $18 \%$ anak tidak menyelesaikan tugas tepat waktu, $32 \%$ tugas di kerjakan kan oleh orangtua, 10\% anak tidak mengerjakan tugas sama sekali.

Pembelajaran yang dilakukan di rumah merupakan tantangan bagi guru, dimana guru harus bisa melakukan kegiatan belajar tetap terlaksana dengan baik walaupun di masa pandemi. Terlebih pada jenjang pendidikan anak usia dini. karakteristik anak usia dini yang baru mengenal lingkungan sekolah (Sutarna et al., 2022). Selain itu karakteristik anak yang masih sering moody pada saat belajar, terkadang anak rajin namun tibatiba anak juga terlihat malas. Tanpa guru yang mendampingi belajar dan juga teman sekelas yang biasa menjadi teman belajar anak tentu merupakan kebiasaan belajar yang baru yang dirasakan anak. Ditambah dengan materi belajar yang hanya mengisi tugas yang berupa LKS membuat anak semakin malas dalam belajar. Hal ini sangat berpengaruh pada berkurangnya motivasi dan semangat belajar anak (Fadlilah, 2020).

Menurut (Yulianingsih et al., 2020) BDR sebagai alternatif pembelajaran yang paling aman selama masa pandemic covid-19 ini. Karena secara umum peran orangtua sebagai peran pendidik pertama dan utama bagi perkembangan anaknya. Selain itu lingkungan rumah juga merupakan lingkungan yang paling aman dan nyaman bagi anak terlebih di masa pandemic seperti ini. Orangtua dapat menciptakan lingkungan yang nyaman sehingga anak bisa belajar dengan baik. Selain itu pendampingan anak selama belajar di rumah selain membantu mengerjakan tugas anak, orangtua juga mampu menyampaikan penjelasan tentang materi pembelajaran yang dilaksanaa dan orangtua juga mampu memberikan respon baik terhadap pembelajaran yang disampaikan sekolah.

Namun tidak semua orangtua yang bisa mendampingi anaknya ketika BDR. (Wardani \& Ayriza, 2020) memaparkan dalam artikelnya kendala-kendala dalam pembelajaran BDR, seperti orangtua yang kurang memahami materi pembelajaran, orangtua yang tidak memiliki waktu untuk mendampingi anak karena kegiatan rutinnya, orangtua yang kurang memahami cara menumbuhkan minat belajar pada anak, orangtua yang kurang sabar dalam mendampingi anak, orangtua yang kurang memahami gadget dan lainlain. Kendala-kendala tersebut dapat diminimalisir dengan komunikasi orangtua dengan guru, guru dapat memberikan masukan-masukan terkait kendala tersebut. Namun keberhasilannya masih belum memuaskan. 
Memasuki tahap kedua, anak-anak akan mulai mengembangkan daya ingat dan imajinasi. Di tahap perkembangan kognitif ini si Kecil juga mulai memahami sesuatu secara simbolik, misalnya dengan mengumpulkan benda-benda berdasarkan kriteria. Sebagai contoh, mengumpulkan semua mainan berwarna merah. Lalu memasuki usia 4-7 tahun, anak juga sudah mulai bisa mengutarakan pemikirannya.(Santrock, 2011). Anak juga belajar melalui lingkungan sosial seperti yang dikemukakan oleh Albert Bandura, bahwa anak usia dini melihat contoh langsung dapat meningkatkan kemampuan anak (Albert, 1977).

Dalam metode pembelajaran BDR ini peran orangtua sangat penting, mengingat orangtua merupakan orang yang dapat langsung berhadapan dengan anak dalam upaya meningkatkan minat belajarnya. Faktor yang menjadi penghambat dalam pembelajaran BDR ini adalah kurangnya motivasi kepada anak dalam menyelesaikan tugas yang disampaikan guru kelas karena pendampingan orangtua dalam proses belajar selama BDR. Semangat pendampingan orangtua pada awal pembelajaran BDR ini lambat laun menurun karena orangtua merasa kerepotan dengan membagi waktu antara pekerjaan rutin dengan mendampingi anak, terkadang anak yang bersemangat belajar tetapi orangtua merasa malas untuk mendampingi atau sebaliknya. Sementara pendidikan anak usia dini masih sangat membutuhkan pendampingan orang dewasa dalam melakukan pembelajaran ini (Fadlilah, 2020).

Siswa TKQ An Namlu kelas B pada tahun ajaran 2020-2021 yang berjumlah 20 anak pada masa pandemic covid-19 mengikuti pembelajaran BDR. Perihal ini dikarenakan BDR merupakan cara yang aman dilakukan pada masa pandemic dalam rangka mengurangi penyebaran virus dan mencegah dari paparannya. Dengan segala upaya guru berusaha menyampaikan materi pembelajaran sebagai acuan orangtua yang akan disampaikankepada anak. Namun, motivasi belajar anak selama BDR dinilai kurang maksimal Terlihat dari hasil laporan penilaian anak pada semester ganjil sekitar 50\% kurang maksimal. Perihal ini diduga karena kurangnya pendampingan orang tua ketika BDR, sehingga menyebabkan anak kurang maksimal dalam menerima pembelajaran.

Peran orang tua juga sangat penting untuk meningkatkan kemampuan anak sekama BDR
(Cahyati \& Kusumah, 2020), kemudian terdapat beberapa dampak positif maupun negatif selama pembelajaran daring, karena cakupannya masih pada anak usia dini, karena anak usia dini masih perlu bimbingan dan arahan secara menyeluruh(Sutarna et al., 2022).

Melihat hal tersebut peneliti memfokuskan penelitiannya pada motivasi belajar anak usia dini terhadap pendampingan orangtua dalam melaksanakan tugas yang diberikan oleh guru. Melalui program kegiatan pada puncak tema berupa kegiatan yang merangsang kerjasama dan kreatifitas antara anak dan orangtua, berharap orangtua dapat melakukan pendampingan dengan maksimal kepada anak dan anak antusias dalam melakukan pembelajaran sehingga motivasi anak dalam belajar dapat meningkat kembali.

\section{METODE PENELITIAN}

\section{Jenis Penelitian}

Jenis penelitian yang digunakan oleh peneliti adalah deskriftif kualitatif. Menurut (Sugiyono, 2015) penelitian kualitatif deskriptif yaitu jenis penelitian untuk mengobservasi suatu kejadian secara keseluruhan, secara umum dan lengkap. Penelitian ini menggunakan jenis penelitian kualitatif karena penelitian ini merupakan peristiwa sosial yang terjadi di masyarakat, yaitu mengkaji tentang motivasi belajar anak usia dini dalam pembelajaran BDR.

\section{Waktu dan Tempat Penelitian}

Penelitian ini dilaksanakan di kelas pembelajaran online atau BDR yang dilakukan di TKQ An Namlu pada semester genap tahun ajaran 20202021. Proses pembelajaran dilakukan di rumah masing-masing dengan pendampingan orangtua dan pantauan dari guru kelas. Guru kelas memantau perkembangan anak melalui grup WhatSapp dan memberikan tugas berupa kegiatan puncak tema yang dapat menambah pengalaman yang menyenangkan pada anak selama belajar dari rumah bersama orangtuanya yaitu menanam bibit pohon dengan membuat kreasi pot dari barang bekas.

\section{Subjek Penelitian}

Subjek penelitian pada artikel ini adalah siswa TKQ An Namlu tahun ajaran 2020-2021 yang berjumlah 20 anak di Karawang Timur, sedangkan sumber informasi dalam penelitian ini adalah anak, orang tua dan guru.

\section{Prosedur}

Prosedur penelitian diawali dengan teridentifikasinya permasalahan pembelajaran, penentuan judul penelitian, penyusunan proposal 
oleh peneliti kemudian melakukan bimbingan dan meminta persetujuan Dosen pembimbing untuk tahap selanjutnya, peneliti menghubungi pihak Fakultas Agama islam dan Prodi Pendidikan Islam Anak Usia Dini Universitas Singaperbangsa Karawang untuk meminta surat izin penelitian. Setelah diperolehnya surat izin penelitian tersebut, peneliti menghubungi pihak lembaga sekolah yang akan diteliti dengan menyampaikan surat resmi dari pihak kampus untuk melakukan penelitian di lembaga tersebut.

Data, Intrumen, dan Teknik Pengumpulan Data Adapun teknik pengumpulan data yang dilakukan oleh peneliti yaitu observasi wawancara, dan dokumen tentang motivasi belajar anak selama di rumah. Pada proses penelitian ini peneliti menggunakan juga pedoman observasi pada pengamatannya selama di lapangan sehingga penelitian memperoleh data-data pendukung yang relevan serta permasalahan dari penelitian tersebut. Wawancara dilakukan pada orang tua peserta didik dan guru, observasi diambil dari data penilaian anak serta dokumentasi diperoleh photo-photo selama belajar yang dikirimkan orang tua kepada grup whatsapp. (Sugiyono, 2015) menyatakan bahwa dalam penelitian kualitatif yang menjadi instrument adalan peneliti itu sendiri. Dalam hal ini peneliti memiliki peranan penting dalam keberhasilan penelitian tersebut. Oleh karena itu instrument utama dalam penelitian motivasi anak dalam belajar di rumah melalui kegiatan puncak tema tanaman ini adalah peneliti itu sendiri. Peneliti merupakan intrumen harus melakukan validasi bahwa sejauh mana peneliti siap melakukan penelitian ini dan dilanjutkan dengan terjun ke lapangan. Validasi peneliti terhadap instrument meliputi beberapa validasi, diantaranya adalah pemahaman pada metode penelitian kualitatif, validasi terhadap penguasaan pengetahuan pada bidang yang diteliti yaitu motivasi belajar anak di rumah pada masa pandemic di TKQ An Namlu Karawang.

\section{Teknik Analisis Data}

Peneliti menggunakan teknik analisis triangulasi. Triangulasi merupakan teknik pengumpulan data yang sifatnya penggabungan keseluruhan data yang berbeda-beda yang didapatkan dari sumber yang sama. (Sugiyono, 2015). Sehingga terdapat 3 jenis triangulasi:

\section{Triangulasi sumber}

Pada triangulasi sumber peneliti mendapatkan data dari beberapa sumber yang kemudian dapat menjelaskan secara rinci dan dapat di kelompokan juga antara pendapat yang sama dan berbeda. Dalam hal ini guru, peserta didik dan orang tua merupakan subjek dari sumber penelitian. Dalam hal ini, ketika peneliti telah mendapatkan data dari beberapa sumber kemudian data tersebut di tuangkan ke dalam bentuk narasi dan dikelompokkan dan kemudian di perhatikan juga mengenai pendapat yang sama, yang berbeda termasuk juga pendapat yang lenih spesifik dari ketiga sumber data tersebut. Sehingga peneliti mendapat kesimpulan yang diperoleh dari data data yang telah diperiksa dari berbagai sumber tersebut oleh peneliti. Dapat dikatakan juga bahwa triangulasi sumber ini merupakan cross check data dengan membandingkan pendapat dari sumber satu dengan sumber yang lainnya (Alfansyur \& Mariyani, 2020).

Triangulasi teknik

Triangulasi teknik yaitu teknik dalam mencari kebenaran data yang diperoleh dari sumber yang sama dengan teknik yang berbeda seperti hasil data wawancara dilakukan pengecekan dengan menggunakan observasi atau dokumentasi, ketika menemukan hasil yang berbeda maka peneliti melakukan diskusi kembali dengan sumber data tersebut. Seperti ketika peneliti mendapatkan data wawancara dengan orang tua yang menyatakan tidak terdapat masalah selama anak mengikuti BDR namun ketika peneliti melihat hasil penilaian dari guru terdapat beberapa aspek yang mendapat nilai berkurang dari biasanya. Akhirnya peneliti melakukan wawancara kembali dengan orang tua supaya mendapatkan hasil yang sesuai antara hasil data wawancara dan observasi. Setelah melakukan wawancara ulang dengan orang tua terdapat data bahwa orang tua tersebut kurang memperhatikan anak selama proses BDR tersebut dikarenakan orang tuanya yang kerja dan pendampingan anak selama belajar dilakukan bersama neneknya. Akhirnya setelah dilakukan pengulangan tersebut didapat hasil yang sesuai.

Triangulasi waktu

Waktu juga merupakan peran aktif dalam melakukan penelitian, misalnya ketika peneliti melakukan wawancara di pagi hari mendapatkan hasil yang baik karena kondisi sumber data masih dalam keadaan fresh, namun ketika wawancara tersebut dilakukan siang atau sore hari mendapatkan hasil yang berbeda. Ketika hal ini terjadi peneliti harus melakukan wawancara berulang hingga mendapatkan hasil yang sesuai (Aisyah et al., 2019). Hal ini terjadi ketika peneliti menanyakan kesiapan anak ketika BDR pada orang tua di waktu pagi hari, menyampaikan anak merasa siap dalam mengikuti proses belajar tersebut. Namun di lain hari dan waktu yang berbeda (siang hari) peneliti menanyakan kembali kesiapan anak 
selama mengikuti BDR dan orang tua menyatakan ketika hari mulai siang anak terlihat malas malasan dalam mengikuti proses belajar tersebut dengan alasan anak sudah merasa bosan karena tidak ada kegiatan yang bervariasi.

\section{HASIL PENELITIAN DAN PEMBAHASAN}

Motivasi belajar merupakan upaya menstimulus dalam diri anak untuk melakukan kegiatan belajar yang bertanggung jawab pada kelangsungan kegiatan belajar dan menyampaikan arahan pada kegiatan belajar tersebut, sehingga tujuan belajar yang diharapkan dapat tercapai. (Sardirman, 2018). Indikator motivasi yaitu: 1) tekun menghadapi tugas, yaitu anak mampu mengerjakan tugas tepat waktu, 2) ulet dalam mengahadapi kesulitan, yaitu anak akan bertanggung jawab dalam menyelesaikan tugasnya, dan yang ke 3) menunjukkan minat, yaitu yaitu anak akan berusaha terus ketika menghadapi kesulitan seperti bertanya kepada orang tua atau guru (Sardirman, 2018).

Kondisi di TKQ An Namlu masih memiliki kondisi motivasi belajar anak yang kurang maksimal selama pembelajaran BDR. Terdapat 20 anak pada kelas B dengan rentang usia 5-6 tahun.

Tekun menghadapi tugas.

Tekun menghadapi tugas yaitu Anak mampu mengerjakan tugasnya sampai selesai. Misalnya anak mengerjakan tugas dengan tepat waktu, ketika menemukan kesulitan anak tidak menyerah berusaha mencari sumber lain sampai menemukan jawaban dari kesulitan tersebut, ketika tugas selesai pun anak melakukan pengecekan terhadap kelengkapan dari tugasnya. Subjek penelitian di TKQ An Namlu yang berjumlah 20 anak ( 9 lakilaki dan 11 perempuan ). Menurut guru kelas dari 20 anak motivasi anak selama BDR kurang maksimal. Hasil wawancara dengan orang tua menyatakan "Gampang bosan karena alasan tidak ada teman dan ibu guru." Adalah alasan rata-rata setiap anak ketika BDR padahal ibu dari subjek $\mathrm{Ar}$ menyampaikan selalu mendampingi anaknya ketika belajar karena kondisi Ar yang anak tungal menjadikan ibunya selalu mendampingi namun Ar merasa jenuh selama belajar.

Berbeda dengan hasil wawancara dari ibu dari $\mathrm{Zh}$ mengatakan "Mengajak teman sekelasnya untuk mengikuti belajar dengan bersama, karena kebetulan rumah kami berdekatan dengan 2 orang temannya". $\mathrm{Zh}$ termotivasi dalam belajarnya karena walaupun pembelajaran BDR masih bisa belajar bersama dengan teman sekelas yang merupakan dari tetangganya.

Berdasarkan hasil wawancara tersebut, ibu dari $\mathrm{Zh}$ terlihat dapat memanfaatka teman sekelas dengan mengajak belajar bersama, hal ini $\mathrm{Zh}$ dan temantemannya dapat mengikuti pembelajaran dengan maksimal sehingga dapat menyelesaikan tugas yang disampaikan guru.

Ulet dalam menghadapi kesulitan

Yaitu anak selalu antusias dalam belajar sekalipun menghadapi kesulitan, anak bertanggung jawab terhadap menyelesaikan tugasnya. Dari hasil wawancara dengan orang tua di TKQ An Namlu didapatkan data dari ibunya $\mathrm{Nl}$ mengatakan bahwa "Mengatur mood anak ketika belajar sangat penting karena anak usia dini tidak bisa dengan paksaan". Namun Nl masih belum menunjukkan antusias dalam belajarnya dan membuat ibu dari $\mathrm{Nl}$ merasa bosan dengan mengingatkan $\mathrm{Nl}$ dalam menyelesaikan tugas. Teman Nl yang suka mengajak bermain bersama menambah kemalasan $\mathrm{Nl}$ untuk menyelesaikan tugasnya, akhirnya ibu $\mathrm{Nl}$ membiarkan anaknya mengabaikan tugas dari guru dengan alasan merasa kerepotan dalam mengajak Nl belajar.

Lain halnya dengan ibu dari $\mathrm{Nu}$ dari hasil wawancaranya mengungkapkan bahwa "Tidak memaksakan, untuk tugas bisa dikerjakan di lain waktu". Ibu $\mathrm{Nu}$ membuat memberikan kebebasan dengan anaknya dalam hal menyelesaikan tugasnya. Dalam hal ini $\mathrm{Nu}$ dan ibunya membuat perjanjian waktu $\mathrm{Nu}$ dalam menyelesaikan tugas dari sekolah, dengan ini $\mathrm{Nu}$ dapat memilih waktu yang tepat antara bermain dan menyelesaikan tugasnya sesuai dengan keinginan dari $\mathrm{Nu}$. Sehingga $\mathrm{Nu}$ merasa tidak terbebani dan dapat menyelesaikan dengan maksimal walaupun $\mathrm{Nu}$ terkadang menemukan kesulitan $\mathrm{Nu}$ akan bertanya pada ibunya, selain itu ibu Nu juga dapat mengajarkan anaknya akan hal tanggung jawab dengan tugas yang harus di selesaikan oleh $\mathrm{Nu}$.

Dari hasil wawancara tersebut ibu $\mathrm{Nl}$ kurang telaten dalam mendampingi anaknya belajar, sehingga ketika $\mathrm{Nl}$ menemukan kesulitan dalam belajarnya $\mathrm{Nl}$ meniggalkan tugas dengan bermain bersama temannya. Nl merasa malas untuk menyelesaikan tugas karena ibunya terkadang kurang sabar dalam menemani Nl. Berbeda dengan sikap ibu $\mathrm{Nu}$ yang memberi kebebasan pada anaknya dan memberikan penjelasan ketika $\mathrm{Nu}$ mendapat kesulitan dalam belajarnya.

Menunjukkan minat. 
Menunjukkan minat merupakan sikap berani menghadapi masalah, ketika menemukan masalah anak tidak putus asa dan berusaha mencari jalan keluarnya. Pada penelitian ini dilakukan wawancara terhadap ibunya Ha menyatakan jika Ha hampir jarang sekali menyelesaikan tugas belajarnya. Kerepotan ibunya dalam menemani anak-anak BDR dan mengasuh anak yang masih balita membuat $\mathrm{Ha}$ enggan menyelesaikan tugasnya. Ha merasa kesulitan dan akhirnya $\mathrm{Ha}$ meninggalkan tugasnya dan memilih bermain bersama teman-teman di sekitar rumahnya. Hal itu tidak terjadi pada Ro, menurut ibunya Ro walaupun jarang mendampingi Ro belajar namun Ro mampu menyelesaikan tugasnya dengan tepat waktu. Biasanya Ro menyelesaikan ketika setelah kegiatan bermain. Ketika menemukan kesulitan dalam belajarnya Ro menanyakan kepada kakak atau ayahnya ketika pulang kerja, Ro akan menunda tugas yang dirasa kesulitan sambil menunggu ayahnya pulang kerja, setelah ayahnya pulang Ro akan meminta ayahnya menjelaskan cara penyelesaiannya dan akhirnya Ro menyelesaikan tugas sekolah dengan tepat waktu.

Melihat hasil wawancara tersebut untuk menunjukkan minat belajar anak dibutuhkan kerjasama antar anggota keluarga. Pendampingan yang dilakukan oleh ayah Ro menjadikan Ro mampu menyelesaikan kesulitan belajar yang di rasakan. Ro tidak bertanya kepada ibunya mengingat Ro memiliki adik bayi dan itu membuat ibunya sibuk dengan kegiatan mengasuh adik bayi. Motivasi belajar sangat diperlukan bagi keberhasilan belajar pada anak terlebih anak usia dini. lingkungan yang nyaman serta pendampingan selama belajar merupakan bagian dari upaya meningkatkan motivasi belajar. Selain itu unsur intrinsik maupun ekstrinsik juga harus dimiliki anak dalam membangun motivasi belajar, karena merupakan bagian yang penting juga agar tujuan pembelajaran yang diharapkan tercapai dengan baik dan anak pun akar menambah semangat belajarnya sehingga anak akan mengetahui arah belajarnya dan mendapatkan hasil yang maksimal dalam proses pembelajarannya (Amirudin et al., 2021).

Peran serta orang tua dalam hal pendampingan sangat penting sekali, mengingat orang tua merupakan orang yang dapat berinteraksi langsung dengan anak dalam pembelajaran di rumah. Walaupun pendampingan ini merupakan tantangan bagi orang tua, dimana mereka harus meluangkan waktu dari kegiatan rutinitas keseharian juga harus mampu menguasai materi yang disampaikan oleh guru (Yulianingsih et al., 2020). Sehingga manfaat yang dapat di ambil dari kegiatan tersebut diantaranya: 1) mampu mendekatkan hubungan antara orang tua dan anak, 2) orang tua mampu membantu anak dalam memecahkan masalah, 3) anak merasa lebih percaya diri, dan 4) dapat menumbuhkan rasa tenang pada anak sehingga anak lebih berkonsentrasi dalam belajarnya. Hal ini sesuai dengan pendapat. Berikut ini dokumentasi hasil dari kegiatan puncak tema tanaman di TKQ An Namlu.

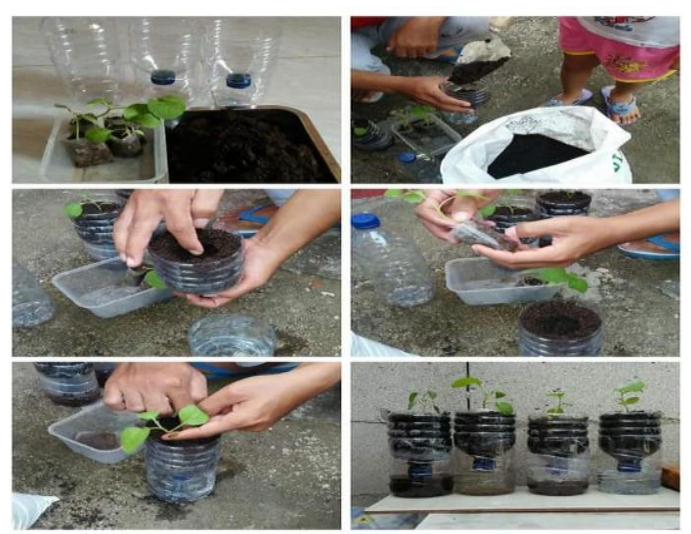

Gambar 1. Kegiatan puncak tema selama BDR

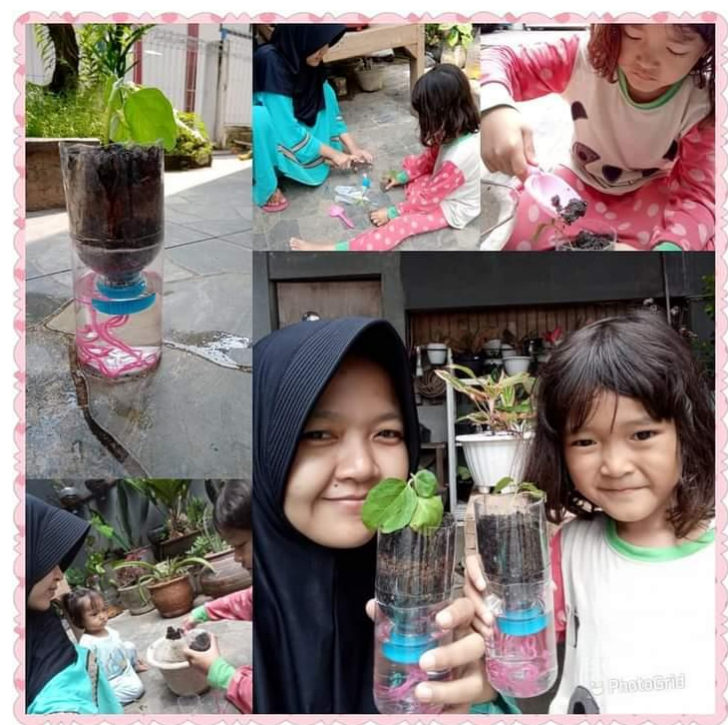

Gambar 2: kegiatan puncak tema 


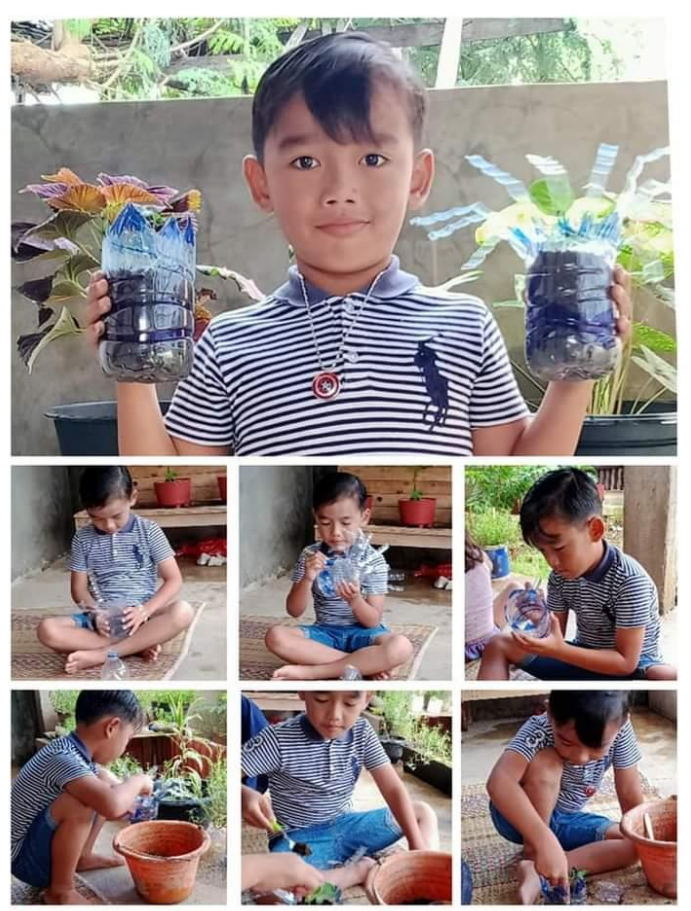

Gambar 3: kegiatan puncak tema

Program puncak tema yang dilakukan guru melalui pendampingan orang tua selama belajar BDR mampu menambah motivasi belajar anak. Hal ini dapat dibuktikan dari hasil penilaian di akhir semester genap sehingga dapat diambil kesimpulan penelitian di TKQ An Namlu Karawang mampu memaksimalkan motivasi belajar pada anak.

\section{SIMPULAN}

Dalam metode pembelajaran BDR ini peran orangtua sangat penting, mengingat orangtua merupakan orang yang dapat langsung berhadapan dengan anak dalam upaya meningkatkan minat belajarnya. Faktor yang menjadi penghambat dalam pembelajaran BDR ini adalah kurangnya motivasi kepada anak dalam menyelesaikan tugas yang disampaikan guru kelas karena pendampingan orangtua dalam proses belajar selama BDR. Semangat pendampingan orangtua pada awal pembelajaran BDR ini lambat laun menurun karena orangtua merasa kerepotan dengan membagi waktu antara pekerjaan rutin dengan mendampingi anak, terkadang anak yang bersemangat belajar tetapi orangtua merasa malas untuk mendampingi atau sebaliknya.

Puncak tema tanaman dalam kegiatan pembelajaran di rumah pada peserta didik di TKQ An Namlu Karawang mampu menambah motivasi belajar anak pada masa pandemi covid-19, terbukti anak bersemangat kembali dalam mengikuti pembelajaran sedangkan dengan menambahnya motivasi anak secara otomatis hasil belajar anak juga menunjukkan hasil yang memuaskan. Hasil tersebut sesuai dengan hasil yang diraih pada motivasi belajar pada anak usia dini dan hasil belajar. Pendampingan dilakukan dengan cara membantu dan menemani anak dalam menyelesaikan tugasnya, memberikan penjelasan tentang materi pembelajaran yang disampaikan guru, memberikan respon yang baik terhadap pembelajaran yang disampaikan guru. Sehingga dengan pendampingan ini mampu membentuk karakter anak yang di harapkan orang tua dan guru terlebih pada pendidikan anak usia dini. Hal ini membuktikan anak mampu melakukan pembelajaran di rumah dan menciptakan hasil karya sebagai wujud dari pembelajaran tersebut.

\section{DAFTAR PUSTAKA}

Aisyah, D. S., Riana, N., \& Putri, F. E. (2019). Peran Ayah (Fathering) Dalam Perkembangan Sosial Anak Usia Dini (Studi Kasus pada Anak Usia 5-6 tahun di RA Nurhalim Tahun Pelajaran 2018). Jurnal Wahana Karay Ilmiah_Pascasarjana (S2) PAI Unsika, 3(1), 294-304.

Albert, B. (1977). Social Learning Theory. PrenticeHall, Inc.

Alfansyur, A., \& Mariyani. (2020). Seni Mengelola Data: Penerapan Triangulasi Teknik, Sumber Dan Waktu Pada Penelitian Pendidikan Sosial. HISTORIS: Jurnal Kajian, Penelitian \& Pengembangan Pendidikan Sejarah, 5(2), 146150.

Amirudin, A., Karochman, M. A., \& Aliyah, A. (2021). Strategi Menghidupkan Motivasi Belajar Siswa Sekolah Dasar di Masa Pandemi Covid-19 Melalui Kelompok Belajar. Etos: Jurnal Pengabdian Masyarakat, 3(1), 37. https://doi.org/10.47453/etos.v3i1.347

Cahyati, N., \& Kusumah, R. (2020). Peran Orang Tua Dalam Menerapkan Pembelajaran Di Rumah Saat Pandemi Covid 19. Jurnal Golden Age, Universitas Hamzanwadi, 04(1), 4-6.

Fadlilah, A. N. (2020). Strategi Menghidupkan Motivasi Belajar Anak Usia Dini Selama Pandemi COVID19 melalui Publikasi. Jurnal Obsesi: Jurnal Pendidikan Anak Usia Dini, 5(1), 373. https://doi.org/10.31004/obsesi.v5i1.548 
Santrock, J. W. (2011). Life Span Development (13th ed.). The McGraw-Hill Companies.

Sardirman. (2018). Interaksi dan Motivasi Belajar Mengajar. PT. Rajagrafindo Persada.

Sugiyono. (2015). METODE PENELITIAN : Kuantitatif, Kualitatif, dan $R \& D$ (22nd ed.). Alfabeta.

Sutarna, N., Acesta, A., Cahyati, N., Giwangsa, S. F., \& Iskandar, D. (2022). Dampak Pembelajaran Daring terhadap Siswa usia 5-8 tahun. 6(1), 288297. https://doi.org/10.31004/obsesi.v5i2.1265

Kemendikbud, 24 Maret 2020, Jakarta, kemdikbud.go.id
Wardani, A., \& Ayriza, Y. (2020). Analisis Kendala Orang Tua dalam Mendampingi Anak Belajar di Rumah Pada Masa Pandemi Covid-19. Jurnal Obsesi : Jurnal Pendidikan Anak Usia Dini, 5(1), 772. https://doi.org/10.31004/obsesi.v5i1.705

Yulianingsih, W., Suhanadji, S., Nugroho, R., \& Mustakim, M. (2020). Keterlibatan Orangtua dalam Pendampingan Belajar Anak selama Masa Pandemi Covid-19. Jurnal Obsesi: Jurnal Pendidikan Anak Usia Dini, 5(2), 1138-1150. https://doi.org/10.31004/obsesi.v5i2.740 